\title{
A study on managerial role of women entrepreneur
}

\author{
MINAXI K. BARIYA AND JIJU VYAS
}

Received: 18.08.2015; Revised: 05.11.2015; Accepted: 15.11.2015

See end of the paper for authors' affiliations MINAXI K. BARIYA

Krishi Vigyan Kendra, PIPALIA (GUJARAT) INDIA

Email : minaxibariya@gmail.com
ABSTRACT : Entrepreneurship has become a defining business trend in many countries throughout the world. Though in the recent years the number of women owned firms with employees has increased considerably, the visibility of the women entrepreneurs in the business arena is still underrepresented. Managerial skill provides an opportunity for self expression and the realization of one's passion for doing something new and different. This paper examines the managerial role of women entrepreneur in Mehsana district of Gujarat State. Drawing from both data collected by author and existing literature on the subject. Samples of 60 respondents were selected for a survey. Structured questionnaire was used to collect the primary data and using survey method. The data analytic tools include frequency, mean, S.D. and t-test. The finding of the study shows that there is a significant relationship between age, education qualification and the length of business. The education and experience also plays a key role for the women to adopt managerial abilities.

KEY WORDS: Entrepreneurship, Women entrepreneur, Managerial skill, Managerial role

— HOW TO CITE THIS PAPER : Bariya, Minaxi K. and Vyas, Jiju (2015). A study on managerial role of women entrepreneur. Asian J. Home Sci., 10 (2) : 400-406. 